
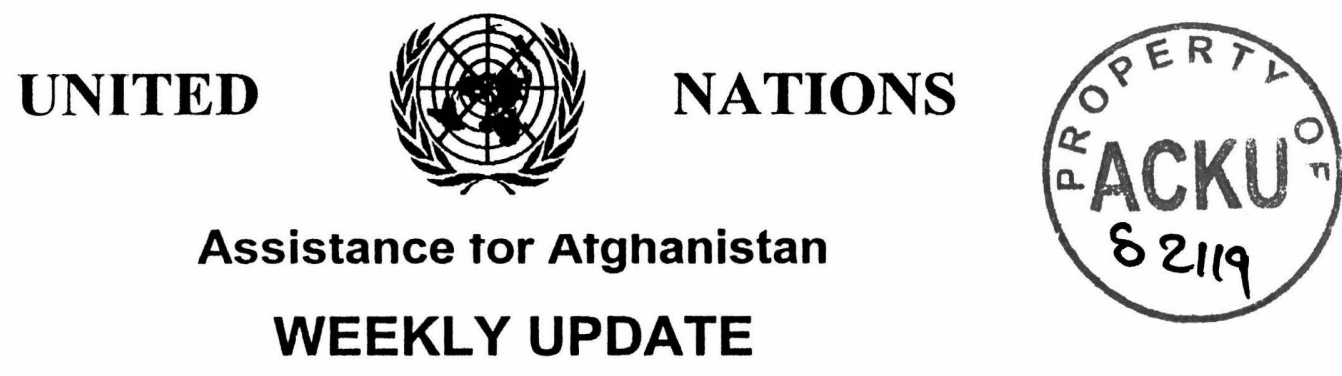

Issue No. 249

20 January 1998

\section{Pledges and contributions}

The Government of India has pledged an in-kind donation of medicines and medical supplies to Afghanistan valued at approximately US\$ 800,000 equivalent. The contribution is being channelled through WHO and coordinated by UNOCHA.

\section{From the frontline}

The general security situation in Kabul has been relatively quiet. Due to severe weather conditions, the front-line to the north and north-east of Kabul is reported to be quiet.

The security situation in Herat is reportedly tense and heavy fighting in Badghis Province is continuing.

Jalalabad City and regional provinces were said to be relatively quiet during the reporting period. On 14 January rockets fired by unknown gunmen killed three and injured seven in front of the Customs Office near the Torkham border. Reports of sporadic fighting in Alishang district were received. Kunar and Ghazni have been reported to be calm. On 13 January ICRC drivers and international staff were stopped at a gunpoint by Arabs from a nearby military base, when driving on the Charbagh road, behind Darunta.

\section{BAAG/PRDU workshop in UK}

The meeting of 70 people, predominantly from NGOs, also included donors, UN representatives and a number of Afghans. The topics were "From Rhetoric to Reality" and "The Role of Aid in Local Peace- building in Afghanistan". The workshop was organised by the British Agencies Afghanistan Group (BAAG), and the Post-war Reconstruction and Development Unit (PRDU) at the University of York. Conclusion: the aid community should further define how it can contribute to peace-building and how its efforts at the local level must be complemented by activities at the national and international level.

\section{Currency regulations}

On 18 January, the Taliban administration announced new controls over the money market. The authorities will fix the afghani/dollar exchange rate on a daily basis in a bid to halt speculation and end wild exchange rate movements.

In non-Taliban areas, the exchange rate currently stands at around 70,000 afghanis to the dollar. In Taliban-controlled regions the Afghani stands at 31,000 to the dollar. Throughout 1997, the rate fluctuated between 21,000 and 26,000 afghanis to the dollar. Meanwhile, there are widespread reports of a large influx of new afghani notes onto the market.

\section{Consolidated appeal}

The 1998 Consolidated Appeal for Afghanistan will be formally launched on Wednesday, 4 February. Copies of the Ap- . peal, which outlines the assistance community's objectives for the current year will be airfreighted to New York and Geneva next week. 


\section{Strategic framework forum}

An e-mail forum will be launched to facilitate consultation on the Framework. Participants will include the aid community, academics and the media. The objective is to ensure that those involved can both access and contribute to current information, documentation and debate. Please e-mail ross@undpafg.org.pk to register.

\section{Humanitarian update}

\section{Central Region}

UNHCR checkposts report that 2,629 people left Kabul City and 781 people entered the city last week. It was said that out of these, 239 people came from Tagab and Nejrab districts in Kapisa Province, which continue to be the focus of hostilities.

The second meeting of the Health Commission, comprising MoPH, UNICEF, WHO, ICRC, UNDP/UNOCHA and an NGO representative, was held in Kabul. The participants discussed ways of resolving operational aspects of health care in the region.

UNICEF continued activities aimed at supporting the control of Acute Respiratory Infection (ARI). They also supported a workshop for mass media personnel and 28 female community workers. An UNICEF mission travelled to Ghazni to deliver supplies to EPI teams and review their activities.

WFP reported distribution of 1,102 tonnes of food through for food-for-work for institutional training and food-fortraining in Kabul.

UNHCR has purchased 415 quilts for distribution to families under the Winter Relief Programme.

With the support from WFP, FAO purchased 50 tonnes of maize seed from farmers in Kabul and Logar Provinces.

\section{Eastern Region}

UNICEF conducted 3 days training on ARI in Kunar and on safe motherhood at the MoPH in Jalalabad. 26 doctors and health workers, 24 social mobilisers and 28 volunteers benefited from this training. UNICEF provided 350 student kits, classroom equipment and 305,000 notebooks to CARE International, in order to support a home based school project in Paktia.

WFP will to support the construction of two MCH clinics in Metherlam and Rodat districts of Laghman and Nangarhar. It is a food-for-work programme and 10 tonnes of wheat will be provided. 100 labourers will benefit from this project. WFP will also provide 164 tonnes of wheat to another food-for-work programme, for construction of flood protection walls in Alishing district in Laghman Province.

\section{Northern Region}

A feeding project, linked to drug detoxification in Ishkashem, Zabak and Wakhan in Faizabad is being extended for another six months. WFP and ORA International undertake the project in which treatment is provided to 720 drug addicts and ex-addicts who are being re-integrated into the society. Awareness of the dangers of drug abuse is also provided.

\section{Western Region}

WHO installed an X-ray machine in Farah hospital and repaired three others in the Province.

FAO Crops planted 20 hectares of improved wheat, 0.5 hectares of onion and 1 hectares of Swedish chick peas.

WFP distributed 306 tonnes of wheat to 874 beneficiaries in Herat, 58 tonnes to IDPs and 54 Tajik refugees.

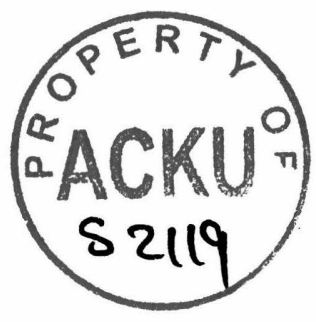

